\title{
A rapid assessment of the decapod fauna in the Rio Tahuamanu and Rio Manuripi Basins, with new records of shrimps and crabs for Bolivia (Crustacea, Decapoda, Palaemonidae, Sergestidae, Trichodactylidae)
}

\author{
Célio Magalhães ${ }^{1,2}$
}

\begin{abstract}
Results of a decapod fauna survey conducted during the AquaRAP expedition to Río Tahuamanu and Río Manuripi Basins, in the Department of Pando, Bolivia, in September, 1996 are presented. Ten species of shrimps and crabs, representing three families and six genera were found. New records for Bolivia were Macrobrachium depressimanum Pereira, 1993, Macrobrachium brasiliense (Heller, 1862), Acetes paraguayensis Hansen, 1919, Sylviocarcinus devillei H. MilneEdwards, 1853, Sylviocarcinus maldonadoensis (Pretzmann, 1978), and Valdivia serrata White, 1847.

KEY WORDS. Bolivia, Decapoda, diversity, Amazon Basin, new record
\end{abstract}

The decapod crustacean fauna of Bolivia is poorly known. Palaemonid shrimps were treated by HolthuIs (1950), who described Palaemonetes ivonicus and later recorded Macrobrachium amazonicum (Heller, 1862) and M. jelskii (Miers, 1877) (Holthuis 1952, 1966). The trichodactylid crabs are relatively better studied. The first citation was by NOBILI (1898) for Orthostoma septemdentatum (Herbst, 1783) based on specimens from Río Yacuma, in the Department of Beni. PARISI (1923) and PRETZMANN (1968) described, respectively, Trichodactylus (Valdivia) boliviensis and Trichodactylus (Dilocarcinus) bachmayeri, based on material from Bolivia. However, these taxa were later synonymized by MAGALHÃES \& TÜRKAY (1996a) under Poppiana argentiniana (Rathbun, 1905). BOTT (1969) mentioned the occurrence of Sylviocarcinus pictus (H. Milne-Edwards, 1853) and Poppiana argentiniana and described Dilocarcinus pagei cristatus. RODRíGUEZ (1992) also dealt with Bolivian specimens in his revision of the family. He described Dilocarcinus truncatus from Riberalta and presented new records for Valdivia camerani (Nobili, 1896) and Dilocarcinus pagei Stimpson, 1861. MAGALHÃES \& TÜRKAY (1996b) recorded Sylviocarcinus pictus (H. Milne-Edwards, 1853) and presented new records of Zichiopsis oronensis (Pretzmann, 1968) for the country. Specimens of anomurans (Aeglidae) were firstly recorded by RINGUELET (1960) as Aegla neuquensis affinis (Schmitt, 1942), which BOND-BUCKUP \& BUCKUP (1994) later described as Aegla septentrionalis new species. This family is represented in Bolivia only by this species, known from the southern Departments of Potosi and Tarija.

1) Instituto Nacional de Pesquisas da Amazônia. Caixa Postal 478, 69011-970 Manaus, Amazonas, Brasil. E-mail: celiomag@inpa.gov.br

2) Research Fellow of the Conselho Nacional de Desenvolvimento Científico e Tecnológico, CNPq.

Revta bras. Zool. 19 (4): 1091 - 1103, 2002 
The above records were considered in the lists of MANNING \& HOBBS JR. (1977) and RODRÍGUEZ (1981) of the aquatic biota of Austral and Tropical South America, respectively. The former authors mentioned Aegla neuquensis affinis and Zichiopsis sattleri Bott, 1969, and the latter listed Zichiopsis sattleri and Poppiana argentiniana for the country.

These sporadic records came mostly from collections undertaken in the Rio Beni and Rio Mamoré Basins. Large areas of the Bolivian territory remain unknown in terms of the presence of shrimps and crabs, as it is the case of the northern Department of Pando. In September, 1996, an AquaRAP (Aquatic Rapid Assessment Program) Expedition to the Rio Tahuamanu and Rio Manuripi Basins was undertaken to perform a rapid biological assessment of the area (CHERNOFF \& WILLINK 1999). Aspects of habitat, distribution and ecological notes about the crustaceans collected in that Expedition have been presented by MAGALHÃES (1999). Here I summarize the taxonomic results and present the distributional data for the decapod species.

\section{MATERIAL AND METHODS}

The surveyed areas of Río Tahuamanu and Río Manuripi are situated in the Department of Pando, northern Bolivia, within a polygon approximately between the meridians $11^{\circ} 00^{\prime}-11^{\circ} 30^{\prime} \mathrm{S}$ and the parallels $67^{\circ} 33^{\prime}-69^{\circ} 00^{\prime} \mathrm{W}$ (Fig. 1). Both rivers join to form the Río Orthon, which runs into the Río Madre de Díos and Río Beni, part of the upper Río Madeira Basin. Rivers are usually white water, slightly acidic to neutral, but some water bodies have blackwater habitats (see CHERNOFF \& WILLINK 1999 for a detailed description of the region and the water quality). Crustaceans were collected as part of the ichthyological survey at 43 stations. The main habitats surveyed were river channel, small forest streams and lagoons. The samples were taken in sandy and muddy-sand beaches, floating and rooted vegetation, and areas with submerged leaf litter and trunks. The methods of capture were mainly 2 and 5-meter long seine nets and, occasionally, trawl gear. All the samples were taken during daylight hours.

Measurements of crab carapace (breadth:length) are in millimeters. Abbreviations used were "immat." for immature specimens; "juv." for juveniles and "spec." for specimens. Only adult males were used for preparing the illustrations. The specimens are deposited in the Colección Boliviana de Fauna (CBF), La Paz, and the crustacean collection of the Instituto Nacional de Pesquisa da Amazônia (INPA), Manaus.

\section{Palaemonidae Rafinesque, 1815}

\section{Macrobrachium amazonicum (Heller, 1862)}

Fig. 2

Palaemon amazonicus Heller, 1862: 418, pl. 2, fig. 45.

Macrobrachium amazonicum; Holthuis, 1952: 18. - Holthuis, 1966: 2. - Magalhães, 1999: 36.

Material. BolíviA, Pando: lago Cañavaral, left bank of Rio Tahuamanu, $11^{\circ} 26.2^{\prime}$ S 6901.9'W, 8.IX.1996, J. Sarmiento \& L.F. Yapur, 1 spec. (CBF 97); Rio Manuripi, ca. $13 \mathrm{~km}$ upriver from Puerto Rico, 16.IX.1996, J. Sarmiento, 


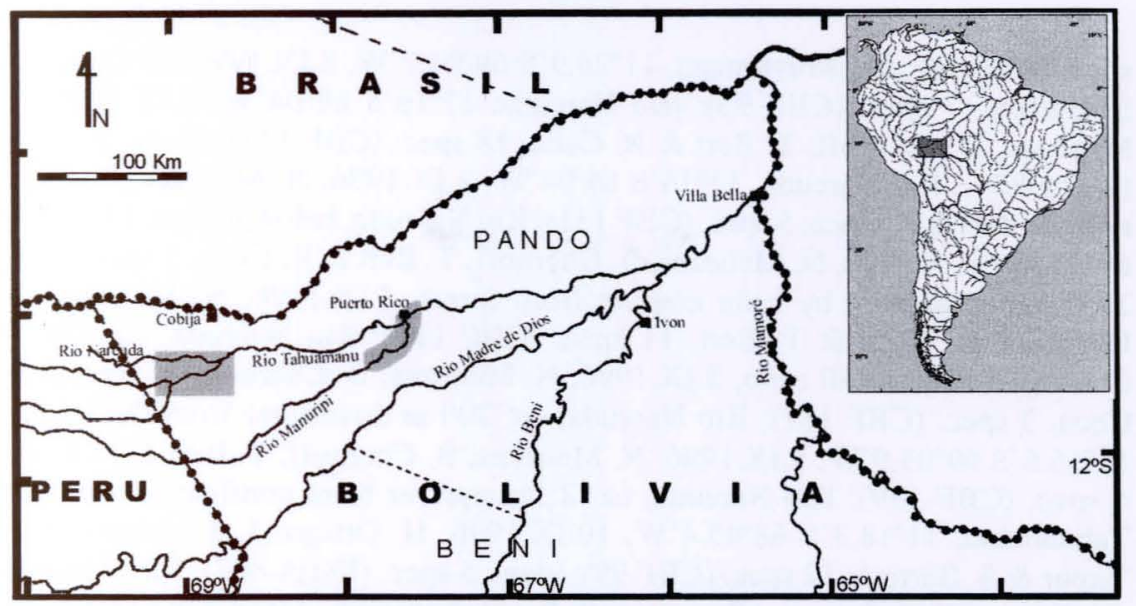

Fig. 1. Map of the surveyed areas of the Río Tahuamanu and Río Manuripi Basins, Bolivia, during the 1996 AquaRAP expedition.

L.F. Yapur \& S. Barrera, 1 spec. (CBF 171); Rio Manuripi, $c a .5 .05 \mathrm{~km}$ upriver from from Puerto Rico, $11^{\circ} 10.8^{\prime} \mathrm{S}$ 67 $33,4^{\prime} \mathrm{W}, 16 . \mathrm{XX}$.1996, A. Machado, B. Chernoff, T. Bert \& R. Coca, $1 \mathrm{spec}$. (CBF 160); lake unnamed, Rio Manuripi, ca. $12 \mathrm{~km}$ upstream from Puerto Rico, 17.IX.1996, J. Sarmiento, L.F. Yapur \& S. Barrera, 1 spec. (CBF 120); Rio Tahuamanu, near mouth in Rio Manuripi, ca. $1 \mathrm{~km}$ above mouth at Puerto Rico, $11^{\circ} 06,7^{\prime} \mathrm{S}$ 67³3,7'W, 17.IX.1996, A. Machado, B. Chernoff, T. Bert \& R. Coca, 3 spec. (CBF 159) lago de la Anguila, Rio Manuripi, ca. $1 \mathrm{~km}$ upstream from the confluence of Rio Manuripi and Rio Tahuamanu, $11^{\circ} 06,7^{\prime}$ S 67³3,3'W, 18.IX.1996, J. Sarmiento, L.F. Yapur \& S. Barrera, 3 spec. (CBF 125); lagoon off Rio Manuripi, $0.8 \mathrm{~km}$ upriver from Puerto Rico, $11^{\circ} 06,6^{\prime}$ ' 6733,3'W, 19.IX.1996, A. Machado, B. Chernoff, T. Bert, F. Yapen \& R. Coca, 70 spec. (CBF 162); idem, 15 spec. (INPA 788).

Remarks. Previous records of this species in Bolivia were made for Rosario (HolthuIs 1952: 22) and Rio Chipiriri, near San Francisco de Chipiriri [Department of Cochabamba, $c a$. 16 $6^{\circ} 45^{\prime} \mathrm{S} 65^{\circ} 11^{\prime} \mathrm{W}$ ] (HOLTHUIS 1966: 2). The species is commonly found in the Rio Madeira drainage, one of the largest tributaries of the Amazon Basin.

\section{Macrobrachium depressimanum Pereira, 1993}

Fig. 3

Macrobrachium depressimanum Pereira, 1993: 339-345, figs 1-2. - Magalhães, 1999: 36.

Material. BoliviA, Pando: Rio Tahuamanu, ca. $2 \mathrm{~km}$ upriver from Aserradero Rutina, $11^{\circ} 26,5^{\prime}$ S 6900,7'W, 4.IX.1996, J. Sarmiento, S. Barrera \& F. Yapur, $10 \mathrm{spec}$. (CBF 88); Rio Tahuamanu, ca. 2-3 km upriver from mouth of Rio Muyumanu, $11^{\circ} 26,3^{\prime}$ 'S 6902,1'W, 5.IX.1996, J. Sarmiento, L.F. Yapur \& S. Barrera, 33 spec. (CBF 90); idem, 6 spec. (INPA 865); Rio Muyumanu, ca. 1.5 $\mathrm{km}$ upriver from the mouth, 5.IX.1996, J. Sarmiento, S. Barrera \& F. Yapur, 1 


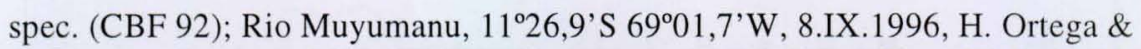
S. Barrera, 7 spec. (CBF 93); Rio Nareuda, $11^{\circ} 16^{\prime}$ 'S 6904'W, 4.IX.1996, N. Menezes, B. Chernoff, T. Bert \& R. Coca, $18 \mathrm{spec}$ (CBF 128); idem, $10 \mathrm{spec}$. (INPA 864); Rio Nareuda, $11^{\circ} 16^{\prime}$ 'S 6904'W, 4.IX.1996, N. Menezes, B. Chernoff, T. Bert \& R. Coca, 5 spec. (CBF 131); Rio Nareuda, below bridge, $11^{\circ} 16.6^{\prime}$ 'S 6903'W, 4.IX.1996, N. Menezes, B. Chernoff, T. Bert \& R. Coca, 2 spec. (CBF 133); Rio Nareuda, by caño coming from forest, 5.IX.1996, N. Menezes, B. Chernoff, R. Coca \& T. Bert, 11 spec. (CBF 134); Rio Nareuda, ca. $100 \mathrm{~m}$ downriver from small caño, 5.IX.1996, N. Menezes, B. Chernoff, T. Bert \& R. Coca, 3 spec. (CBF 137); Rio Nareuda, ca. $200 \mathrm{~m}$ downriver from the bridge, $11^{\circ} 16.6^{\prime}$ 'S 690․ ${ }^{\circ}$ 'W, 5.IX.1996, N. Menezes, B. Chernoff, T. Bert \& R. Coca, 4 spec. (CBF 139); Rio Nareuda, ca. $2 \mathrm{~km}$ upriver from confluence with Rio Tahuamanu, $11^{\circ} 18.3^{\prime}$ S 6845.4'W, 10.IX.1996, H. Ortega, J. Sarmiento, L.F. Yapur \& S. Barrera, $12 \mathrm{spec}$. (CBF 99); idem, $5 \mathrm{spec}$. (INPA 867); Rio Nareuda, ca. $4 \mathrm{~km}$ upriver from confluence with Rio Tahuamanu, $11^{\circ} 18.3^{\prime} \mathrm{S} 68^{\circ} 45.9^{\prime} \mathrm{W}$, 10.IX.1996, H. Ortega \& F. Yapur, 1 spec. (CBF 106); Rio Nareuda, 100 m upriver from confluence with Rio Tahuamanu, 10.IX.1996, H. Ortega \& F. Yapur, 1 spec. (CBF 107); Rio Nareuda, rápidos, $c a .6 \mathrm{~km}$ upriver from confluence with Rio Tahuamanu, $11^{\circ} 18,3^{\prime} \mathrm{W} 68^{\circ} 45.4^{\prime} \mathrm{W}, 11 . \mathrm{IX} .1996$, J. Sarmiento, H. Ortega, S. Barrera \& F. Yapur, 1 spec. (CBF 112); Rio Tahuamanu, downriver from mouth of Rio Nareuda, $11^{\circ} 17.6^{\prime}$ S $68^{\circ} 44.3^{\prime} W, 10 . I X .1996$, N. Menezes, B. Chernoff, T. Bert \& R. Coca, $10 \mathrm{spec}$. (CBF 144); Rio Tahuamanu, ca. $1 \mathrm{~km}$ downriver from mouth of Rio Nareuda, $11^{\circ} 16.4^{\prime} \mathrm{S} 68^{\circ} 44.2^{\prime} \mathrm{W}, 10 . \mathrm{IX} .1996, \mathrm{~N}$. Menezes, B. Chernoff, T. Bert \& R. Coca, 4 spec. (CBF 146); Rio Tahuamanu, ca. $1.9 \mathrm{~km}$ downriver from mouth of Rio Nareuda, $11^{\circ} 17.5^{\prime}$ 'S $68^{\circ} 44.4^{\prime} \mathrm{W}, 10 . \mathrm{IX} .1996, \mathrm{~N}$. Menezes, B. Chernoff, T. Bert \& R. Coca, 2 spec. (CBF 145); Rio Tahuamanu, $11^{\circ} 16.3^{\prime}$ 'S 68 $44^{\prime}$ 'W, 10.IX.1996, B. Chernoff, J. Sarmiento, S. Barrera, R. Coca $\&$ T. Bert, 2 spec. (CBF 148); Rio Tahuamanu, ca. $68 \mathrm{~km}$ downriver from mouth of Rio Nareuda, $11^{\circ} 18.1^{\prime} \mathrm{S} 68^{\circ} 44.4^{\prime}$ W, B. Chernoff, H. Ortega, N. Menezes, T. Bert \& R. Coca, 4 spec. (CBF 151); Rio Tahuamanu, ca. $440 \mathrm{~m}$ upriver from mouth of Rio Nareuda, at small rapids, $11^{\circ} 18.8^{\prime}$ 'S $68^{\circ} 44.5^{\prime} \mathrm{W}, 12 . \mathrm{IX} .1996, \mathrm{H}$. Ortega, B. Chernoff, N. Menezes, T. Bert \& R. Coca, 2 spec. (CBF 152); Rio Tahuamanu, from mouth of Rio Nareuda to below Cochuelita (from $0.15 \mathrm{~km}$ to $4.55 \mathrm{~km}$ below mouth of Rio Nareuda), 13.IX.1996, H. Ortega, B. Chernoff, T. Bert \& R. Coca, 6 spec. (CBF 153); Rio Tahuamanu, at sand island ca. $1.93 \mathrm{~km}$ downriver from mouth of Rio Nareuda, 13.IX.1996, B. Chernoff, A. Machado, J. Sarmiento, T. Bert, R. Coca \& F. Yapur, 17 spec. (CBF 155); Rio Tahuamanu, near mouth in Rio Manuripi, $11^{\circ} 06.7^{\prime}$ S 67³3.7'W, 17.IX.1996, A. Machado, B. Chernoff, T. Bert \& R. Coca, 25 spec. (CBF 159); idem, 15 spec. (INPA 866); Rio Tahuamanu, ca. $500 \mathrm{~m}$ upriver from confluence with Rio Manuripi, 18.IX. 1996, J. Sarmiento, S. Barrera \& F. Yapur, 5 spec. (CBF 124); Rio Orthon, ca. 2 km downriver from Puerto Rico, $11^{\circ} 05.3$ 'S 67³3.4'W, 18.IX.1996, J. Sarmiento, S. Barrera \& F. Yapur, 4 spec. (CBF 122).

Remarks. This is the first record of the species in Bolivia, but PEREIRA (1993: 342) already recorded it in the Rio Madeira Basin in Brazil. 


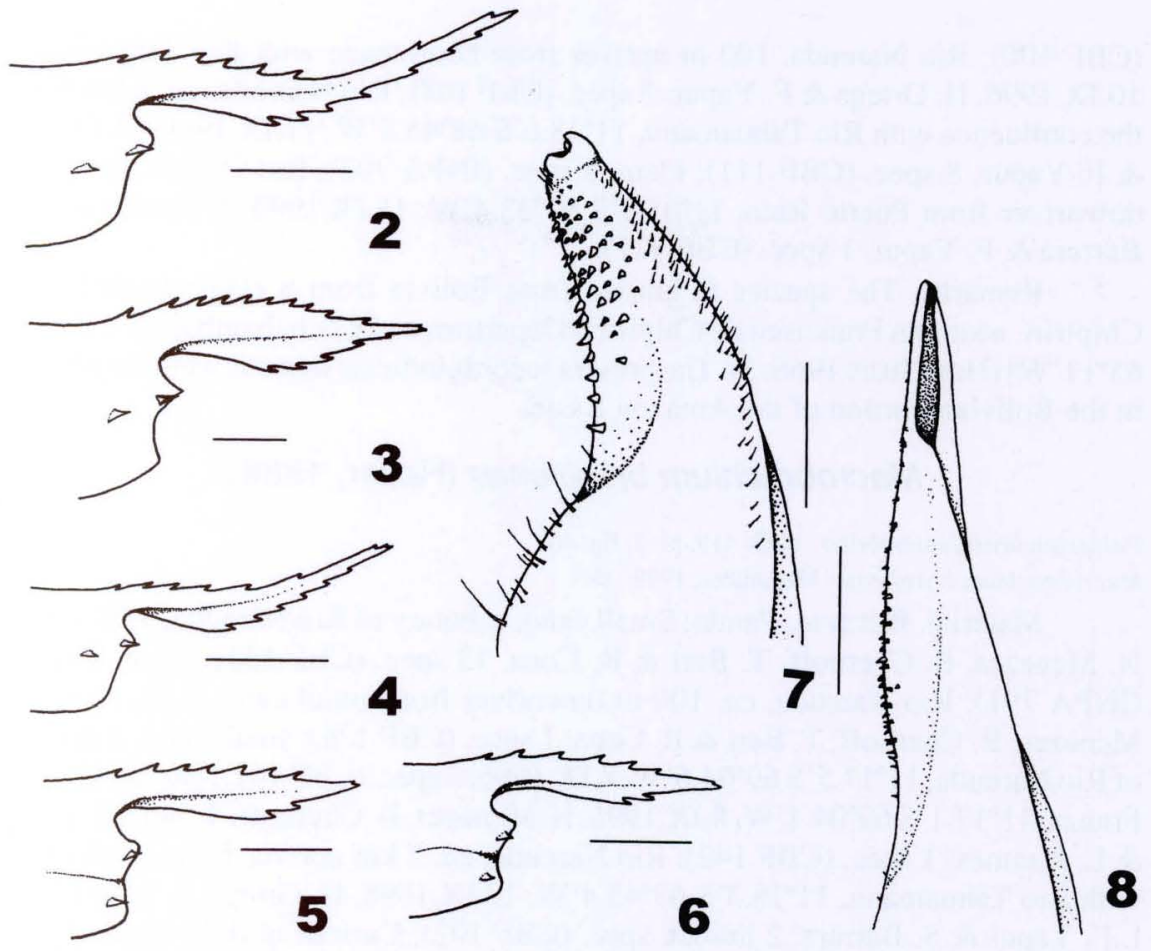

Figs 2-8. (2) Macrobrachium amazonicum, male, INPA 788, rostrum and anterior part of the carapace, lateral view; (3) Macrobrachium depressimanum, male, INPA 866, rostrum and anterior part of the carapace, lateral view; (4) Macrobrachium jelskii, male, INPA 792, rostrum and anterior part of the carapace, lateral view; (5-6) Palaemonetes ivonicus, males, INPA 869, rostrum and anterior part of the carapace, lateral view; (7) Valdivia serrata, INPA 790, first gonopod of male, right, distal part, ventro-mesial view; (8) Zilchiopsis oronensis, INPA 789, first gonopod of male, right, distal part, ventro-mesial view. Scale bars: $2,4=5 \mathrm{~mm} ; 3,5,6=$ $2 \mathrm{~mm} ; 7,8=1 \mathrm{~mm}$.

\section{Macrobrachium jelskii (Miers, 1877)}

Fig. 4

Palaemon jelskii Miers, 1877: 661, pl. 67, fig. 1.

Macrobrachium jelskii; Holthuis, 1966: 3. - Magalhães, 1999: 36.

Material. BoliviA, Pando: lago Cañavaral, left bank of Rio Tahuamanu, $11^{\circ} 26.2^{\prime}$ S 6901.9'W, 8.IX.1996, J. Sarmiento \& L.F. Yapur, 1 spec. (CBF 96); Rio Nareuda, ca. $100 \mathrm{~m}$ downriver from small caño, 5.IX.1996, N. Menezes, B. Chernoff, T. Bert \& R. Coca, 2 spec. (CBF 136); Rio Nareuda, $11^{\circ} 16^{\prime}$ 'S 6904' W, 4.IX.1996, N. Menezes, B. Chernoff, T. Bert \& R. Coca, 10 spec. (CBF 130); Rio Nareuda, ca. $2 \mathrm{~km}$ upriver from confluence with Rio Tahuamanu, $11^{\circ} 18.3^{\prime} \mathrm{S}$ $68^{\circ} 45.4^{\prime}$ W, 10.IX.1996, H. Ortega, J. Sarmiento, L.F. Yapur \& S. Barrera, $10 \mathrm{spec}$. 
(CBF 100); Rio Nareuda, $100 \mathrm{~m}$ upriver from confluence with Rio Tahuamanu, 10.IX.1996, H. Ortega \& F. Yapur, 3 spec. (CBF 108); Rio Nareuda, ca. 6 km from

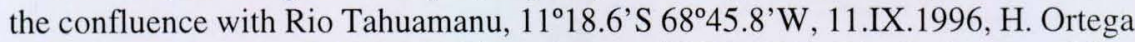
\& F. Yapur, 8 spec. (CBF 111); idem, 8 spec. (INPA 792); Rio Orthon, ca. $2 \mathrm{~km}$

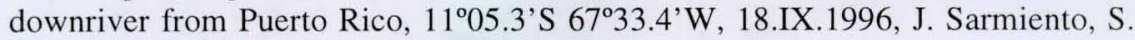
Barrera \& F. Yapur, 1 spec. (CBF 121).

Remarks. The species in known from Bolivia from a single record: Rio Chipiriri, near San Francisco de Chipiriri [Department of Cochabamba, ca. 16 ${ }^{\circ} 45^{\prime}$ S $65^{\circ} 11^{\prime} \mathrm{W}$ ] (HOLTHUIS 1966: 3 ). The present records indicate that it is well distributed in the Bolivian portion of the Amazon Basin.

\section{Macrobrachium brasiliense (Heller, 1866)}

Palaemon brasiliensis Heller, 1862: 419, pl. 2, fig. 46.

Macrobrachium brasiliense; Magalhães, 1999: 36.

Material. BolIVIA, Pando: Small caño, tributary of Rio Nareuda, 5.IX.1996, N. Menezes, B. Chernoff, T. Bert \& R. Coca, 13 spec. (CBF 135); idem, 2 spec. (INPA 791); Rio Nareuda, $c a .100 \mathrm{~m}$ downriver from small caño, 5.IX.1996, N. Menezes, B. Chernoff, T. Bert \& R. Coca, 1 spec. (CBF 138); small caño, tributary of Rio Nareuda, $11^{\circ} 17.5^{\prime} \mathrm{S} 69^{\circ} 04.6^{\prime} \mathrm{W}$, 8.IX.1996, $2 \mathrm{spec}$. (CBF 141); garape Campo Franza, $11^{\circ} 17.1^{\prime}$ 'S 6904.4'W, 8.IX.1996, N. Menezes, B. Chernoff, T. Bert, R. Coca \& L. Jammes, $1 \mathrm{spec}$. (CBF 142); Rio Nareuda, ca. $2 \mathrm{~km}$ upriver from confluence with Rio Tahuamanu, $11^{\circ} 18.3^{\prime}$ S 68²45.4'W, 10.IX.1996, H. Ortega, J. Sarmiento, L.F. Yapur \& S. Barrera, 2 immat. spec. (CBF 102); Curiche at right bank of Rio Nareuda, ca. 3-4 km upriver from the confluence with Rio Tahuamanu, 10.IX.1996, H. Ortega, J. Sarmiento, S. Barrera \& F. Yapur, 2 spec. (CBF 103); Rio Nareuda, ca. $4 \mathrm{~km}$ upriver from confluence with Rio Tahuamanu, $11^{\circ} 18.3^{\prime} \mathrm{S} 68^{\circ} 45.9^{\prime} \mathrm{W}$, 10.IX.1996, H. Ortega \& F. Yapur, 1 spec. (CBF 105); Rio Nareuda, 100 m upriver from confluence with Rio Tahuamanu, 10.IX.1996, H. Ortega \& F. Yapur, $1 \mathrm{spec}$. (CBF 109); garape Preto, ca. $300 \mathrm{~m}$ above mouth in Rio Tahuamanu, $4.36 \mathrm{~km}$ downriver from mouth of Rio Nareuda, 11.IX.1996, N. Menezes, B. Chernoff, T. Bert \& R. Coca, 3 spec. (CBF 149).

Remarks. Part of the material is composed by immature or damaged specimens, which makes the identification difficult. However, a few fully grown adult males have the second pereiopod bearing the typical morphology, with a subcylindrical palm more than two times as long as the fingers.

\section{Palaemonetes ivonicus Holthuis, 1950}

Figs 5,6

Palaemonentes ivonicus Holthuis, 1950: 98. - Holthuis, 1966: 4, fig. 1a,b. - Magalhães, 1999: 36. Palaemonetes (Palaemonetes) ivonicus; Holthuis, 1950: 10. - Holthuis, 1952: 222, pl. 53, figs d-h.

Material. BoliviA, Pando: Rio Tahuamanu, Aserradero Rutina, $77 \mathrm{~km}$ de

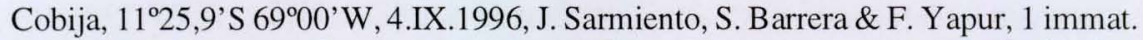
spec. (CBF 164); lago Cañavaral, left bank of Rio Tahuamanu, $11^{\circ} 26.2^{\prime} \mathrm{S} 69^{\circ} 01.9^{\prime} \mathrm{W}$, 8.IX.1996, J. Sarmiento \& L.F. Yapur, 1 spec. (CBF 95); Rio Muyumanu, 11²6,9'S 
6901,7’W, 8.IX.1996, H. Ortega \& S. Barrera, 4 juv. spec. (CBF 166); Rio Nareuda, $100 \mathrm{~m}$ upriver from confluence with Rio Tahuamanu, 10.IX.1996, H. Ortega \& F. Yapur, $10 \mathrm{spec}$. (INPA 869); Curiche at right bank of Rio Nareuda, ca. 3-4 km upriver from the confluence with Rio Tahuamanu, 10.IX.1996, H. Ortega, J. Sarmiento, S. Barrera \& F. Yapur, 15 spec. (CBF 104); idem, 5 spec. (INPA 868); Rio Nareuda, $c a$.

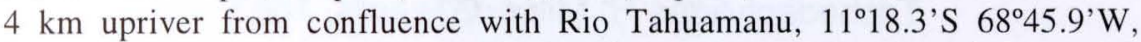
10.IX.1996, H. Ortega \& F. Yapur, 9 juv. and immat. spec. (CBF 167); Rio Manuripi,

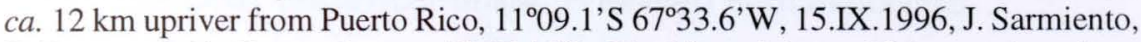
S. Barrera \& F. Yapur, $2 \mathrm{spec}$. (CBF 118); Rio Manuripi, ca. $20 \mathrm{~km}$ upriver from Puerto Rico, 16.IX.1996, J. Sarmiento, F. Yapur \& S. Barrera, 1 spec. (CBF 119); Rio Manuripi, ca. 13 km upriver from Puerto Rico, 16.IX.1996, J. Sarmiento, L.F. Yapur \& S. Barrera, 2 spec. (CBF 170).

Remarks. The rostrum of the specimens is straight and has seven to eight dorsal and two to three ventral teeth; one dorsal tooth is always postorbital. The number of dorsal teeth lays within the range of the Bolivian specimens studied by Holthuis $(1950,1966)$, in which the rostral formula is 6-10/3, but most of the specimens studied by me had only two ventral teeth. The present specimens also had the branchiostegal spine placed behind the anterior margin of the carapace, but the position of its tip is variable. In most cases, the tip does not reach the margin. However, in some specimens, the spine is larger and its tip reaches the anterior margin or even extends beyond it.

The type locality of this species is in the Rio Beni, near Ivon [Department

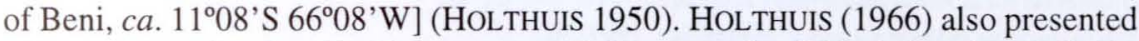
other records for the Rio Palmar, near Palmar, north of Cochabamba, and Rio Chipiriri, near San Francisco de Chipiriri [Department of Cochabamba, ca. $16^{\circ} 45^{\prime} \mathrm{S}$ $\left.65^{\circ} 11^{\prime} \mathrm{W}\right]$.

\section{Sergestidae Dana, 1852}

\section{Acetes paraguayensis Hansen, 1919}

Acetes paraguayensis Hansen, 1919: 46, figs 8-14. - Magalhães, 1999: 36.

Material. BoliviA, Pando: Rio Tahuamanu, downriver from mouth of Rio Nareuda, $11^{\circ} 17.6^{\prime}$ 'S $68^{\circ} 44.3^{\prime}$ W, 10.IX.1996, N. Menezes, B. Chernoff, T. Bert \& R. Coca, 6 spec. (CBF 143); Rio Tahuamanu, $c a .1 \mathrm{~km}$ downriver from mouth of Rio Nareuda, 11⒗4'S 6844.2'W, 10.IX.1996, N. Menezes, B. Chernoff, T. Bert $\&$ R. Coca, 3 spec. (CBF 147); Laguna on right bank of Rio Tahuamanu, ca. 500 m from confluence with Rio Nareuda, $11^{\circ} 18.6^{\prime}$ ' 6844.4'W, 12.IX.1996, J. Sarmiento, F. Yapur \& S. Barrera, 1 spec. (CBF 115); Rio Tahuamanu, at sand island ca. $1.93 \mathrm{~km}$ downriver from mouth of Rio Nareuda, 13.IX.1996, B. Chernoff, A. Machado, J. Sarmiento, T. Bert, R. Coca \& F. Yapur, $34 \mathrm{spec}$ (CBF 154); Rio Manuripi, $5.2 \mathrm{~km}$ from Puerto Rico, $11^{\circ} 09^{\prime} \mathrm{S} 67^{\circ} 33.6^{\prime} \mathrm{W}$, A. Machado, B. Chernoff, J. Sarmiento, R. Coca, T. Bert \& S. Barrera, 4 spec. (CBF 157); lagoon off Rio Manuripi, 0.8 km upriver from Puerto Rico, 1106,6'S 67³3,3'W, 19.IX.1996, A. Machado, B. Chernoff, T. Bert, F. Yapen \& R. Coca, 1 spec. (CBF 163). 
Remarks. A. paraguayensis has a wide distribution in South America, occurring in the Orinoco, Amazon, Paraguay and Paraná River Basins, from Venezuela to Argentina (RODRÍGUEZ 1982). The above records indicate that the species may also be well distributed in the Bolivian portion of the Rio Madeira Basin.

\section{Trichodactylidae H. Milne-Edwards, 1853 Sylviocarcinus devillei $\mathrm{H}$. Milne-Edwards, 1853}

Sylviocarcinus devillei $\mathrm{H}$. Milne-Edwards, 1853: 215. - Magalhães, 1999: 36.

Material. Bolivia, Pando: Rio Tahuamanu, ca. 2-3 km upriver from mouth

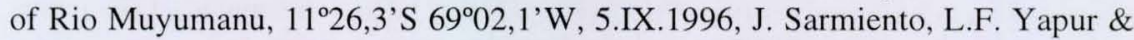
S. Barrera, 1 male (CBF 91); Rio Tahuamanu, ca. $68 \mathrm{~km}$ downriver from mouth of Rio Nareuda, $11^{\circ} 18.1^{\prime} \mathrm{S} 68^{\circ} 44.4^{\prime} \mathrm{W}, \mathrm{B}$. Chernoff, H. Ortega, N. Menezes, T. Bert \& R. Coca, 1 immat. female (CBF 150); Rio Orthon, ca. $2 \mathrm{~km}$ downriver from Puerto Rico, $11^{\circ} 05.3^{\prime}$ S $67^{\circ} 33.4^{\prime}$ W, 18.IX.1996, J. Sarmiento, S. Barrera \& F. Yapur, 1 spec. (CBF 123).

Remarks. The species was previously recorded from the upper (Puerto Maldonado, Peru) and lower (Rio Madeira, Brazil) portions of the Rio Madeira drainage (MAGALHÃES \& TÜRKAY 1996b).

\section{Sylviocarcinus maldonadoensis (Pretzmann, 1978)}

Holthuisia picta maldonadoensis Pretzmann, 1978: 169, fig. 12.

Sylviocarcinus maldonadoensis; Magalhães, 1999: 36.

Material. BoliviA, Pando: Rio Nareuda, $c a .2 \mathrm{~km}$ upriver from confluence with Rio Tahuamanu, $11^{\circ} 18.3^{\prime}$ 'S 6845.4'W, 10.IX.1996, H. Ortega, J. Sarmiento, L.F. Yapur \& S. Barrera, 1 male (CBF 101); Rio Nareuda, rápidos, $c a .6 \mathrm{~km}$ upriver from

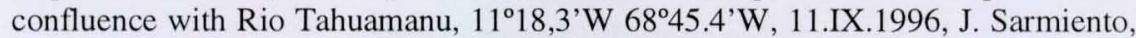
H. Ortega, S. Barrera \& F. Yapur, 1 female (CBF 113); Rio Tahuamanu, at sand island ca. $1.93 \mathrm{~km}$ downriver from mouth of Rio Nareuda, 13.IX.1996, B. Chernoff, A. Machado, J. Sarmiento, T. Bert, R. Coca \& F. Yapur, 1 female (CBF 156).

Remarks. The type material of this species came from Puerto Maldonado, Peru, in the Río Madre de Dios, a tributary of the Río Beni.

\section{Valdivia serrata White, 1847}

Fig. 7

Valdivia serrata White, 1847: 206.

Valdivia cf. serrata; Magalhães, 1999: 36.

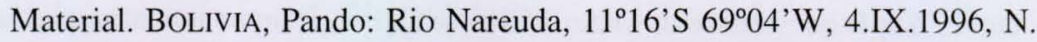
Menezes, B. Chernoff, T. Bert \& R. Coca, 1 male, 33.5:29.3 (CBF 127); idem, 1 male, 33.5:29.0 (INPA 790); Rio Nareuda, $11^{\circ} 16^{\prime}$ 'S 6904'W, 4.IX.1996, N. Menezes, B. Chernoff, T. Bert \& R. Coca, 2 males (CBF 129); small river at bridge on road to Cobija, $11^{\circ} 14.4^{\prime}$ 'S 6859'W, 7.IX.1996, N. Menezes, B. Chernoff, T. Bert \& R. Coca, 1 immat. female (CBF 140); Quebrada unnamed, left bank of Rio Muyumanu, $11^{\circ} 27.5^{\prime}$ S $69^{\circ} 01.9^{\prime} \mathrm{W}, 8 . I X .1996$, H. Ortega \& S. Barrera, 1 immat. 
female (CBF 94); Rio Manuripi, ca. 13 km upriver from Puerto Rico, 16.IX.1996, J. Sarmiento, L.F. Yapur \& S. Barrera, 2 immat. females (CBF 169).

Remarks. The species is widely distributed throughout the Orinoco and Amazon River Basins and shows a considerable variability in the carapace and the first gonopod of males (RoDRíGUEZ 1992). The present specimens had an almost flat carapace, with four sharp teeth along the anterolateral border, the two posteriormost teeth being smaller than the anterior ones. The distal portion of the first gonopod of males is moderately curved $\left(\mathrm{ca} .35-40^{\circ}\right)$ ventrolaterally; the subterminal spine field is well developed, with a patch of small, stout spines on the ventrolateral side, and a patch of short, slender spines on the mesial side.

\section{Zilchiopsis oronensis (Pretzmann, 1968)}

Fig. 8

Valdivia (Valdivia) serrata oronensis Pretzmann, 1968: 72.

Zilchiopsis sattleri Bott, 1969: 34. - Manning \& Hobbs Jr., 1977: 160. - Rodríguez, 1981: 48.

Zilchiopsis oronensis; Magalhães, 1999: 36.

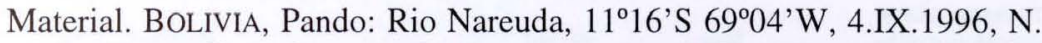
Menezes, B. Chernoff, T. Bert \& R. Coca, 1 male (CBF 126); idem, 1 male, 37.1:31.6 (INPA 789); Rio Nareuda, $c a .2 \mathrm{~km}$ upriver from confluence with Rio Tahuamanu, $11^{\circ} 18.3^{\prime}$ 'S 68º45.4'W, 10.IX.1996, H. Ortega, J. Sarmiento, L.F. Yapur \& S. Barrera, 2 males (CBF 98);

Remarks. The first gonopod of males displays a thin distal end, which is short relative to the length of the subterminal spine-field area. The carapace has four sharp teeth along the anterolateral border. MAGALHÃES \& TÜRKAY (1996b) described its geographic distribution as northern Paraguay, Bolivia and Brazil, and recorded the occurrence of the species in some localities of the Río Beni system.

\section{DISCUSSION}

A total of 16 species of decapod crustaceans, from four families, are known to occur in Bolivia (Tab. I). All the species found in the Tahuamanu and Manuripi systems have wide distributions in the Amazon basin and have already been recorded from other localities in the Brazilian and Peruvian Amazon; some also occur in the Orinoco and Paraguay rivers basins (HOLTHUIS 1952, 1966; BоTT 1969; OMORI 1975; RODRÍGUEZ 1982, 1992; COELHO \& RAMOS-PORTO 1985; PEREIRA 1993; MAGALHÃES \& TÜRKAY 1996b). The distribution of these species is usually related to the sediment-rich white water rivers, which form large areas that are periodically flooded (várzea). Their occurrence in the surveyed area was expected as the Rio Tahuamanu has some typical white water river features, such as high turbidity, $\mathrm{pH}$ near neutrality, and relatively high conductivity.

On the other hand, it is remarkable that some species commonly found in such habitats were not captured. The presence of the shrimp Euryrhynchus amazoniensis Tiefenbacher, 1978, which occurs in the Central Amazon várzea and in the Madeira River Basin (TIEFENBACHER 1978), was expected, as well as Dilocarcinus pagei, a freshwater crab widely distributed in the floodplain areas of the Amazon 
Table I. List of decapod crustaceans recorded from Bolivia.

\begin{tabular}{|c|c|c|c|}
\hline Species & Departments & Localities & References \\
\hline \multicolumn{4}{|l|}{ Palaemonidae } \\
\hline \multirow[t]{3}{*}{ Macrobrachium amazonicum } & ? Beni & Rosario & Holthuis (1952) \\
\hline & Cochabamba & Rio Chipiriri (Rio Mamoré drainadge) & Holthuis (1966) \\
\hline & Pando & $\begin{array}{l}\text { Rio Tahuamanu and Rio Manuripi } \\
\text { drainadges }\end{array}$ & Present paper \\
\hline Macrobrachium brasiliense & Pando & Rio Tahuamanu drainadge & Present paper \\
\hline Macrobrachium depressimanum & Pando & $\begin{array}{l}\text { Río Tahuamanu and Río Manuripi } \\
\text { drainadge }\end{array}$ & Present paper \\
\hline \multirow[t]{2}{*}{ Macrobrachium jelskii } & Cochabamba & Río Chipiriri (Rio Mamoré drainadge) & Holthuis (1966) \\
\hline & Pando & $\begin{array}{l}\text { Río Tahuamanu and Río Manuripi } \\
\text { drainadges }\end{array}$ & Present paper \\
\hline \multirow[t]{4}{*}{ Palaemonetes ivonicus } & Beni & Ivon (Rio Beni) & Holthuis (1950) \\
\hline & Cochabamba & $\begin{array}{l}\text { Rio Palmar; Río Chipiriri (Rio Mamoré } \\
\text { drainadge) }\end{array}$ & Holthuis (1966) \\
\hline & & $\begin{array}{l}\text { Rio Tahuamanu and Rio Manuripi } \\
\text { drainadges }\end{array}$ & Holthuis (1966) \\
\hline & Pando & $\begin{array}{l}\text { Rio Tahuamanu and Río Manuripi } \\
\text { drainadges }\end{array}$ & Present paper \\
\hline \multicolumn{4}{|l|}{ Sergestidae } \\
\hline Acetes paraguayensis & Pando & $\begin{array}{l}\text { Rio Tahuamanu and Río Manuripi } \\
\text { drainadges }\end{array}$ & Present paper \\
\hline \multicolumn{4}{|l|}{ Trichodactylidae } \\
\hline \multirow[t]{3}{*}{ Dilocarcinus pagei } & Beni & Trinidad & Rodríguez (1992) \\
\hline & Beni & Rio Yacuma (Río Mamoré drainadge) & Bott (1969) \\
\hline & Cochabamba & Río Chipiriri (Río Mamoré drainadge) & Bott (1969) \\
\hline Dilocarcinus truncatus & Beni & Riberalta & Rodríguez (1992) \\
\hline \multirow[t]{2}{*}{ Poppiana argentiniana } & Pando & Ingavi (Rio Orthon) & Pretzmann $(1968,1979)$ \\
\hline & Beni & Riberalta & Bott (1969) \\
\hline Sylviocarcinus devillei & Pando & Rio Tahuamanu and Rio Orthon & Present paper \\
\hline Sylviocarcinus maldonadoensis & Pando & Rio Tahuamanu drainadge & Present paper \\
\hline Sylviocarcinus pictus & Cochabamba & Río Chipiriri (Río Mamoré drainadge) & $\begin{array}{l}\text { Bott (1969); Magalhāes \& } \\
\text { Türkay (1996b) }\end{array}$ \\
\hline Valdivia camerani & Beni & Trinidad (Río Mamoré) & Rodríguez (1992) \\
\hline Valdivia serrata & Pando & $\begin{array}{l}\text { Rio Tahuamanu and Rio Manuripi } \\
\text { drainadges }\end{array}$ & Present paper \\
\hline \multirow[t]{2}{*}{ Zilchiopsis oronensis } & Beni & $\begin{array}{l}\text { Rio Yacuma (Rio Mamoré drainadge; } \\
\text { Trinidad }\end{array}$ & Magalhães \& Türkay (1996b) \\
\hline & Pando & Rio Tahuamanu drainadge & Present paper \\
\hline \multicolumn{4}{|l|}{ Aeglidae } \\
\hline \multirow[t]{2}{*}{ Aegla septentrionalis } & Potosi & Tupiza & $\begin{array}{l}\text { Ringuelet (1960); Bond-Buckup } \\
\text { \& Buckup (1994) }\end{array}$ \\
\hline & Tarija & Rio Sella; Mendez & Bond-Buckup \& Buckup (1994) \\
\hline
\end{tabular}

and Paraguay/Paraná River Basins (RODRíGUEZ 1992), usually associated with floating vegetation. E. amazoniensis is a tiny shrimp occurring in cryptic habitats, mainly in the patches of submerged leaf litter near the water edge or in holes and fissures in submerged wood. The collecting gear used primarily for fishes was probably not appropriate for catching this species. It is surprising, however, that the crab D. pagei did not appear in the collections. This is a very common species in floodplains of white water rivers in both the Amazon and Paraguay River Basins, and ihabits habitats similar to those surveyed in the Tahuamanu and Manuripi River Basins, and is usually caught by the fishing methods employed by the AquaRAP ichthyology team. Considering the habitat similarities and the fact that the species is widely distributed in the Río Madeira drainage, the occurrence of this species in the Río Orthon drainage is highly probable. 
Other species, such as Dilocarcinus truncatus, Popianna argentiniana, Sylviocarcinus pictus e Valdivia camerani, also widespread throughout the Amazon Basin, or already recorded in the Bolivian territory of the Río Madeira drainage, were not collected as well. The absence of some, or even all, of these species among the material examined might be related to employing inappropriate collecting gear and the short collecting period for each station, rather than indicating that they do not occur in the surveyed area. On the other hand, the presence of anomuran crabs of the family Aeglidae was not expected. This group is restricted to temperate and subtropical zones of South America and the occurrence of a single species, Aegla septentrionalis, in southern Bolivia marks the northern limits of the genus distribution (BOND-BUCKUP \& BUCKUP 1994).

Some taxa recorded for Bolivia have been synonymized by later revisions. The specimens from Río Yacuma (Department of Beni) treated by NOBILI (1898) as Orthostoma septemdentatum are probably Dilocarcinus pagei, as the author suggests that those specimens have a prominent crest on the third abdominal somite, a character found only in the latter species. PRETZMANN (1979) stated that the type locality of Poppiana bachmayeri is Ingavi, a village on the left bank of the Río Orthon (Department of Pando); this taxon was considered a junior synonym of Dilocarcinus argentinianus by RODRíGUEZ (1992) and as Poppiana argentiniana by MAGALHÃES \& TÜRKAY (1996a). Trichodactylus (Valdivia) boliviensis, described by PARISI (1923) from Misiones Mosetenes [? Department of Cochabamba], was synonymized under Poppiana argentiniana by MAGALHÃES \& TÜRKAY (1996a). The type material of BOTT's (1969) species, Zilchiopsis sattleri, consists of specimens classified under two taxa: the holotype, from Río Chapare, Bolivia, under Z. collastinensis (Pretzmann, 1968) and the paratypes, from the Paraguayan Chaco, under Z. oronensis (see MAGALHÃES \& TÜRKAY 1996b). However, the type locality of $Z$. sattleri was considered dubious by these authors due to inaccurate label information, as the holotype belongs to a species whose distribution is probably restricted to Argentina.

Even including the new records made in the present paper, the number of 16 decapod species known to occur in Bolivia is still very low, given the extent of the country's hydrographic system and diversity of environments. More intensive and comprehensive collecting efforts will certainly increase this number and give a better idea of the composition and distribution of the decapod fauna of the country.

ACKNOWLEDGEMENTS. I thank the AquaRAP ichthyology team (B. Chernoff, J. Sarmiento, S. Barrera, A. Machado-Allison, H. Ortega, N. Menezes, T. Bert) for collecting the decapods, J. Sarmiento for providing the CBF catalogue numbes, The Rufford Foundation and W. Alton Jones Foundation for funding the Bolivian expedition and supporting the AquaRAP Program, William Magnusson for kindly checking the English of this paper, G.A.S. de Melo and G. Bond-Buckup for helpful suggestions that improved the manuscript, and Conselho Nacional de Desenvolvimento Científico e Tecnológico - CNPq, Brazil, for an ongoing research fellowship (Bolsa de Pesquisa nr 300443/92-7). 


\section{REFERENCES}

Bond-Buckup, G. \& L. Buckup. 1994. A família Aeglidae (Crustacea, Decapoda, Anomura). Arq. Zool., São Paulo, 32 (4): 159-346.

BotT, R. 1969. Die Süßwasserkrabben Süd-Amerikas und ihre Stammesgeschichte. Eine Revision der Trichodactylidae und der Pseudothelphusidae östlich der Anden (Crustacea, Decapoda). Abh. Senckenberg. Naturforsch. Ges., Frankfurt a.M., 518: 1-94.

Chernoff, B. \& P.W. Willink. 1999. A Biological Assessment of the Aquatic Ecossystems of the Upper Río Orthon Basin, Pando, Bolivia. Washington, D.C., Conservation International, 145p.

(Bulletin of Biological Assessment 15)

CoElho, P.A. \& M. RAmos-PorTo. 1985. Camarões de água doce do Brasil: distribuição geográfica.

Revta bras. Zool., Curitiba, 2 (6): 405-410.

Hansen, H.J. 1919. The Sergestidae of the Siboga Expedition. Siboga Exped., Leiden, mon. 38: 1-65. HELLER, C. 1862. Beiträge zur näheren Kentniss der Macrouren. S. B. Akad. Wiss. Wien 45 (1): 389-426. Holthuis, L.B. 1950. Preliminary descriptions of twelve new species of palaemonid prawns from America waters (Crustacea Decapoda). Proc. Kon. nederl. Akad. Wetensch, Amsterdam, 53 (1): 93-99.

1952. A general revision of the Palaemonidae (Crustacea Decapoda Natantia) of the Americas. II. The subfamily Palaemonidae. Occ. Pap. Allan Hancock Found., Los Angeles, 12: $1-396$.

HolthuIs, L.P. 1966. A collection of freshwater prawns (Crustacea Decapoda, Palaemonidae) from Amazonia, Brazil, collected by Dr. G. Marlier. Bull. Inst. r. Sci. nat. Belg., Bruxelas, 42 (10): 1-11.

MAGALHÃES, C. 1999. Diversity and abundance of decapods crustaceans in the rio Tahuamanu and rio Manuripi basins, p. 35-38. In: B. CHERNOFF \& P.W. Willink (Eds). A Biological Assessment of the Aquatic Ecossystems of the Upper Río Orthon Basin, Pando, Bolivia. Washington, D.C., Conservation International, 145p. (RAP Bulletin of Biological Assessment 15)

MAgAlHÃEs, C. \& M. TÜRKAY. 1996a. Taxonomy of the Neotropical freshwater crab family Trichodactylidae I. The generic system with description of some new genera (Crustacea: Decapoda: Brachyura). Senckenbergiana biol., Frankfurt a.M., 75 (1/2): 63-95.

1996b. Taxonomy of the Neotropical freshwater crab family Trichodactylidae II. The genera Forsteria, Melocarcinus, Sylviocarcinus, and Zilchiopsis (Crustacea: Decapoda: Brachyura). Senckenbergiana biol., Frankfurt a.M., 75 (1/2): 97-130.

MANning, R.B. \& H.H. Hobbs JR. 1977. Decapoda, p. 157-162. In: S.H. Hurlbert (Ed.). Biota Acuática de Sudamerica Austral. San Diego, San Diego State Univ., 342p.

MIERS, E.J. 1877. On a collection of Crustacea, Decapoda and Isopoda, chiefly from South America, with descriptions of new genera and species. Proc. Zool. Soc. Lond. 1877: 653-679.

Milne-Edwards, H. 1853. Mémoire sur la famille des Ocypodiens. Annls Sci. nat. Zool., Paris, 20 (3): 163-226.

NoBILI, G. 1898. Sopra alcuni decapodi terrestri e d'acqua dolce dell'America meridionale. Ann. Mus. Civ. Stor. Nat. Genova, ser. 2a 19 (39): 9-14.

OMORI, M. 1975. The systematics, biogeography, and fishery of epipelagic shrimps of the genus Acetes (Crustacea, Decapoda, Sergestidae). Bull. Ocean Res. Inst. Univ. Tokyo, Tóquio, (7): 1-89.

Parisi, B. 1923. Un nuovo Potamonide americano. Ann. Mus. Civ. Stor. Nat. Genova 51: 29-30.

PereirA, G. 1993. A description of a new species of Macrobrachium from Perú, and distributional records for Macrobrachium brasiliense (Heller) (Crustacea: Decapoda: Palaemonidae). Proc. Biol. Soc. Wash., Lawrence, 106 (2): 339-345.

PretZmann, G. 1968. Weitere neue südamerikanische Süßwasserkrabben (Voräufige Mitteilung). Ent. NachrBl., Viena, 15 (2): 1-6.

1978. Neue Süßwasserkrabben aus den Anden. Sitz.-Ber. österr. Akad. Wiss. math. naturw. Kl., Viena, (1) 187 (6-10): 163-170

1979. Poppiana bachmayeri nov. comb. Ann. Naturhistor. Mus. Wien 82: 591-593.

RINGUELET, R.A. 1960. Identificación de los crustaceos anomuros del genero Aegla de la Republica de

Revta bras. Zool. 19 (4): 1091 - 1103, 2002 
Bolivia. In: Congresso Sudamericano de Zoologia, $1^{\circ}$, La Plata, Actas y Trabajos 2 (Secc. 3): 245-249.

Rodríguez, G. 1981. Decapoda, p. 41-51. In: S.H. Hurlbert; G. Rodríguez \& N.D. Santos (Eds). Aquatic Biota of Tropical South America, part 1: Arthropoda. San Diego, San Diego State Univ., XII+323p.

- 1982. Fresh-water shrimps (Crustacea, Decapoda, Natantia) of the Orinoco Basin and the Venezuelan Guayana. Jour. Crust. Biol., Lawrence, 2 (3):378-391.

- 1992. The Freshwater Crabs of America. Family Trichodactylidae and Supplement to the Family Pseudothelphusidae. Paris, Editions ORSTOM, 189p. (Collection Faune Tropicale 31)

Tiefenbacher, L. 1978. Zur Systematik und Verbreitung der Euryrhynchinae (Decapoda, Natantia, Palaemonidae). Crustaceana, Leiden, 35 (2): 178-189.

WhITE, A. 1847. Short descriptions of some new species of Crustacea in the collection of the British Museum. Ann. Mag. nat. Hist., Londres, 1 (20): 205-207.

Received in 13.III.2002; accepted in 09.X.2002. 